\title{
Interactions of corn meal or molasses with a soybean-sunflower meal mix or flaxseed meal on production, milk fatty acid composition, and nutrient utilization in dairy cows fed grass hay-based diets ${ }^{1}$
}

\author{
A. F. Brito, ${ }^{* 2}$ H. V. Petit,† A. B. D. Pereira, ${ }^{*}$ K. J. Soder, $\ddagger$ and S. Ross ${ }^{*}$ \\ *Department of Biological Sciences, University of New Hampshire, Durham 03824 \\ †Dairy and Swine Research and Development Centre, Agriculture and Agri-Food Canada, Sherbrooke, QC, Canada J1M 0C8 \\ fUSDA-Agricultural Research Service, Pasture Systems and Watershed Management Research Unit, University Park, PA 16802
}

\begin{abstract}
We investigated the interactions of corn meal or molasses [nonstructural carbohydrate (NSC) supplements] with a soybean-sunflower meal mix or flaxseed meal [rumen-degradable protein (RDP) supplements] on animal production, milk fatty acids profile, and nutrient utilization in dairy cows fed grass hay diets. Eight multiparous and 8 primiparous Jersey cows averaging $135 \pm 49 \mathrm{~d}$ in milk and $386 \pm 61 \mathrm{~kg}$ of body weight in the beginning of the study were randomly assigned to 4 replicated $4 \times 4$ Latin squares with a $2 \times 2$ factorial arrangement of treatments. Each period lasted $19 \mathrm{~d}$ with $14 \mathrm{~d}$ for diet adaptation and $5 \mathrm{~d}$ for data and sample collection. Cows were fed diets composed of mixedmostly grass hay plus 1 of the following 4 concentrate blends: (1) corn meal plus a protein mix containing soybean meal and sunflower meal; (2) corn meal plus flaxseed meal; (3) liquid molasses plus a protein mix containing soybean meal and sunflower meal; or (4) liquid molasses plus flaxseed meal. Data were analyzed for main effects of NSC and RDP supplements, and the NSC $\times$ RDP supplement interactions. Significant NSC $\times$ RDP supplement interactions were observed for milk urea $\mathrm{N}$, milk $\mathrm{N}$ efficiency, and the sums of milk saturated, monounsaturated, and polyunsaturated fatty acids. No effect of NSC supplements was observed for nutrient intake and milk yield. However, $4 \%$ fatcorrected milk $(-0.70 \mathrm{~kg} / \mathrm{d})$ and energy-corrected milk $(-0.60 \mathrm{~kg} / \mathrm{d})$ were significantly reduced in cows fed liquid molasses due to a trend to decreased concentration of milk fat $(-0.17 \%)$. Diets with liquid molasses resulted in increased $(+35 \%)$ concentration and yield of milk enterolactone, indicating that this mammalian lignan can be modulated by supplements with different NSC profiles. Overall, NSC and RDP supplements pro-
\end{abstract}

Received May 12, 2014.

Accepted September 23, 2014.

${ }^{1}$ Contribution no. 2580 from the New Hampshire Agricultural Experiment Station.

${ }^{2}$ Corresponding author: andre.brito@unh.edu foundly changed the milk fatty acid profile, likely because of differences in fatty acids intake, $\Delta^{9}$-desaturase indices, and ruminal biohydrogenation pathways. Feeding liquid molasses significantly reduced plasma urea $\mathrm{N}(-1.2 \mathrm{mg} / \mathrm{dL})$, urinary $\mathrm{N}$ excretion $(-20 \mathrm{~g} / \mathrm{d})$, and $\mathrm{N}$ digestibility ( -3.2 percentage units). Flaxseed meal significantly reduced yields of milk $(-1.3 \mathrm{~kg} / \mathrm{d})$, milk fat $(-90 \mathrm{~g} / \mathrm{d})$, and milk lactose $(-60 \mathrm{~g} / \mathrm{d})$, but significantly increased the concentration and yield of milk enterolactone. Further research is needed to elucidate the negative responses of flaxseed meal on yields of milk and milk components.

Key words: grass hay, flaxseed meal, lactating dairy cow, liquid molasses

\section{INTRODUCTION}

There is a renewed interest in the use of sugarcane molasses in both conventional (Oelker et al., 2009; Martel et al., 2011; Siverson et al., 2014) and organic (Soder et al., 2012) dairy systems in the United States. Anecdotal claims in a case study conducted by Soder et al. (2012) suggest that organic dairy farmers in the northeastern United States are feeding liquid molasses as the sole energy supplemental source to forage-based diets in levels ranging from 1.1 to $2.4 \mathrm{~kg} /$ cow per day (DM basis) depending on milk yield, BCS, and breeding performance, with inconsistent results in animal production and health. Using the mean DMI of 18 $\mathrm{kg} / \mathrm{d}$ calculated from a comprehensive survey of Wisconsin organic dairy farms (Hardie et al., 2014) and a concentration of $60 \%$ of total sugars in liquid molasses (value derived from the current study), the 1.1- to 2.4$\mathrm{kg}$ range would be equivalent to 3.7 to $8.0 \%$ of added sugars from molasses, with the highest level exceeding the recommendation of 2.5 to $5.0 \%$ of added sugars in dairy diets (Firkins, 2010). Interestingly, previous research in which high amounts of dried molasses (up to $12 \%$ of diet DM or $4.6 \%$ added sugars) or liquid molasses (up to $9 \%$ of diet DM or $7.4 \%$ added sugars) were fed to dairy cows, milk production responded cubically or quadratically, whereas OM digestibility increased 
linearly or responded cubically (Broderick and Radloff, 2004). Because of these inconsistent results and lack of data regarding the effect of high dietary levels of liquid molasses, as the major NSC supplemental source, on milk production and nutrient utilization in cows fed grass hay-based diets, further research is needed to fill this knowledge gap.

The outer fiber-containing layer of flaxseed is the richest source of polyphenolic compounds known as lignans (Adlercreutz and Mazur, 1997) and classified as phytoestrogens (Stopper et al., 2005), with secoisolariciresinol diglucoside (SDG) accounting for over $95 \%$ of total flaxseed lignans (Thompson et al., 1991). The rumen appears to be the major site for conversion of SDG into the mammalian lignans enterodiol and enterolactone according to previous research (Côrtes et al., 2008; Gagnon et al., 2009; Zhou et al., 2009). There is growing interest in promoting the inclusion of SDGrich foods in human diets due to the potential human health benefits of enterolactone and enterodiol, including prevention of cardiovascular diseases, hypercholesterolemia, breast and prostate cancers, menopausal symptoms, and osteoporosis (Murkies et al., 1998; Adlercreutz, 2002).

It is hypothesized that feeding carbohydrate supplements (e.g., corn meal vs. liquid molasses) with different NSC profiles (i.e., starch vs. sucrose) and rates of ruminal degradation could affect the microbial conversion of flaxseed meal-SDG into enterolactone, thus resulting in different milk output of this mammalian lignan. It is also hypothesized that feeding corn meal or liquid molasses in combination with a soybean-sunflower meal mix or flaxseed meal could lead to NSC $\times$ RDP supplement interactions, with potential implications on milk production, milk FA profile, and nutrient utilization in dairy cows. The objectives of the current study were to investigate interactions of corn meal or liquid molasses with a soybean-sunflower meal mix or flaxseed meal as the major NSC or RDP supplements on milk production and composition, plasma concentration of the antioxidant enzymes superoxide dismutase (SOD) and glutathione peroxidase (GPx), and nutrient utilization in dairy cows fed grass-fed based diets.

\section{MATERIALS AND METHODS}

Care and handling of the animals used in the current study were conducted as outlined in the guidelines of the University of New Hampshire Institutional Animal Care and Use Committee (IACUC Protocol \# 091102). The 76-d long experiment was conducted at the University of New Hampshire Burley-Demeritt Organic Dairy Research Farm $\left(43^{\circ} 10^{\prime} \mathrm{N}, 70^{\circ} 99^{\prime} \mathrm{W}\right)$ from March 8 to May 24, 2010.

\section{Animals, Experimental Design, and Diets}

Eight multiparous Jersey cows averaging (mean \pm SD) $170 \pm 40 \mathrm{DIM}, 431 \pm 20 \mathrm{~kg}$ of BW, and $15.6 \pm 1.6$ $\mathrm{kg}$ of milk/d, and 8 primiparous Jersey cows averaging $107 \pm 36 \mathrm{DIM}, 351 \pm 59 \mathrm{~kg}$ of BW, and $13.7 \pm 1.9 \mathrm{~kg}$ of milk/d at the beginning of the study were used. Animals were randomly assigned to treatment sequences in a replicated $4 \times 4$ Latin square design with a $2 \times 2$ factorial arrangement of treatments. Distribution of animals to squares was done to balance for differences in DIM, milk production, and parity, resulting in 2 squares of primiparous cows (square $1=79 \pm 17$ DIM and $13.4 \pm$ $0.85 \mathrm{~kg}$ of milk/d; square $2=118 \pm 14$ DIM and 14.1 $\pm 2.9 \mathrm{~kg}$ of milk/d) and 2 squares of multiparous cows (square $3=144 \pm 28$ DIM and $14.6 \pm 0.87 \mathrm{~kg}$ of milk/d; square $4=199 \pm 22$ DIM and $16.2 \pm 1.8 \mathrm{~kg}$ of milk/d). Treatment sequences within each Latin square were balanced for carryover effects in subsequent periods. Each period lasted $19 \mathrm{~d}$ with $14 \mathrm{~d}$ for diet adaptation and $5 \mathrm{~d}$ for data and sample collection. Cows were fed diets formulated to yield (DM basis) a 70:30 forage to concentrate ratio across treatments and were composed of a mixed-mostly grass hay plus 1 of the following 4 concentrate blends: (1) corn meal plus a protein mix containing soybean meal and sunflower meal (CM); (2) corn meal plus flaxseed meal $(\mathbf{C M}+\mathbf{F X})$; (3) liquid molasses plus a protein mix containing soybean meal and sunflower meal (MOL); or (4) liquid molasses plus flaxseed meal (MOL+FX). Animals were housed in a bedded-pack barn with dried pine shavings as bedding material, and were maintained in the same pen separated from the remaining cows in the herd. The bedded area $\left(132 \mathrm{~m}^{2}\right)$ opened to a $478-\mathrm{m}^{2}$ cement-floor outdoor lot (total pen area $=610 \mathrm{~m}^{2}$ ) allowing cows to walk freely to comply with the USDA National Organic Program "Pasture Rule" (USDA-AMS, 2010), which calls for year-round access to the outdoors for all ruminant animals. A roof-covered feeding station equipped with electronic recognition Calan doors system (American Calan Inc., Northwood, NH) was located at the end of the cement-floor lot.

Nutrient composition of the feedstuffs used in the current experiment is shown in Tables 1 and 3 , and ingredient and nutrient composition of the concentrate mixes are shown in Tables 2 and 3. The forage was cut on September 25, 2009 (second cutting), from 2 fields with similar botanical composition using a flail-type mower centerline conditioner (model FC353RGC, Kuhn North America Inc., Brodhead, WI), tedded (model GA7302DL, Kuhn), and field-wilted to about 85\% DM, which was attained approximately $72 \mathrm{~h}$ after cutting. Dried forage was then harvested as hay using a large round baler with a crop cutter (model BR740A; New 
Table 1. Nutrient composition (\% of DM unless otherwise noted) of mixed-mostly grass hay and RDP and NSC supplements fed to lactating dairy cows

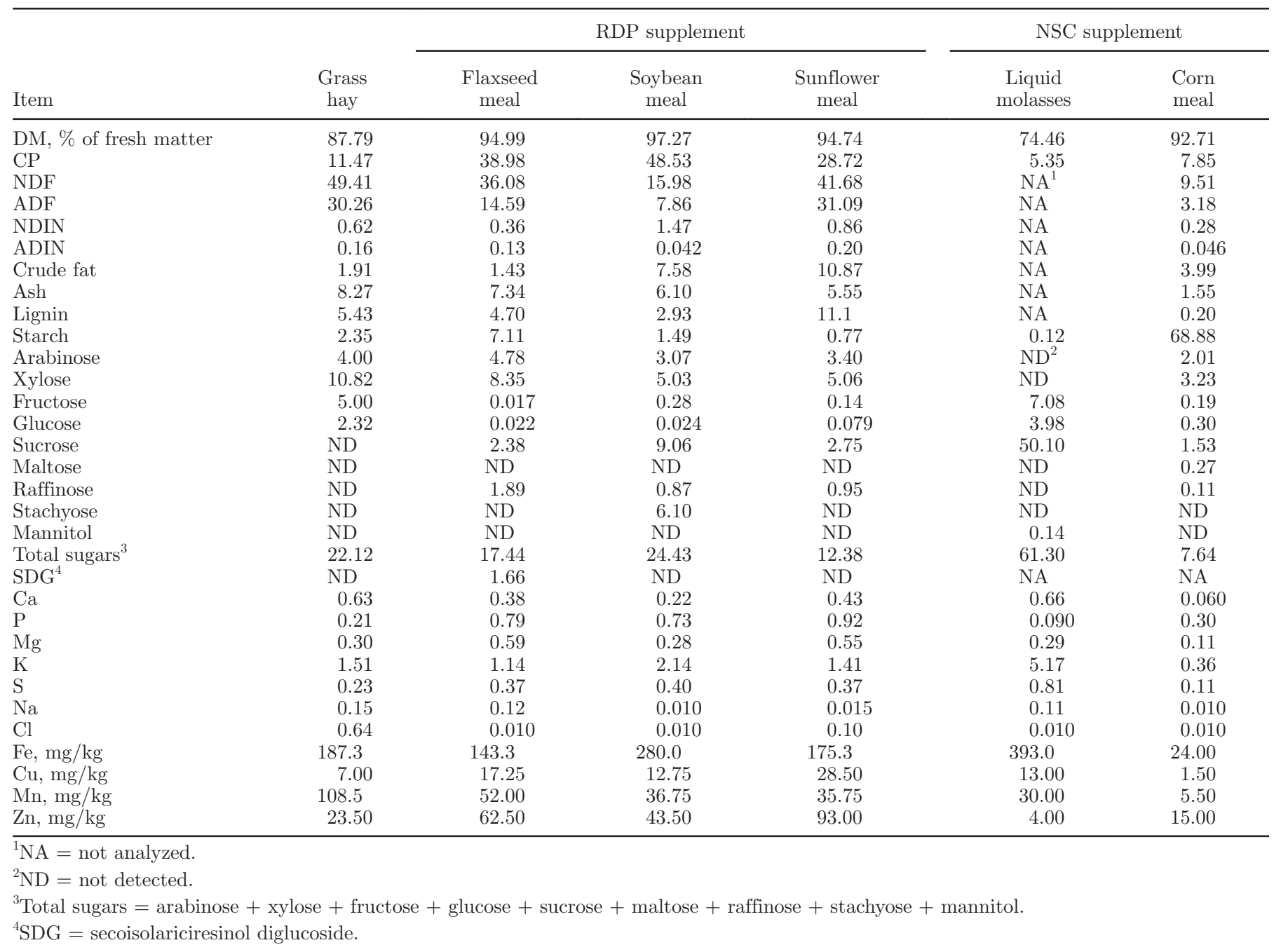

Holland Agriculture, New Holland, PA), wrapped with stretch plastic using a bale wrapper (model 991BJS; McHale Engineering Ltd., Ballinrobe, Ireland) without preservative, and stored in the field. Fields were composed mostly of grass species [i.e., timothy grass $(P h$ leum pretense), orchardgrass (Dactylis glomerata L.), Kentucky bluegrass (Poa pratensis L.), and tall fescue (Festuca arundinacea Schreb.)] with a lower proportion of legume species [i.e., red clover (Trifolium pratense L), alfalfa (Medicago sativa L.), and white clover (Trifolium repens L.)].

\section{Animal Feeding and Feed Sampling and Analyses}

All bales used in the current study were sampled before feeding using a model TE 7-A drill (Hilti Corp., Schaan, Liechtenstein) fitted with a metal core sampler (40 cm long). Throughout the study, approximately 250-g hay samples were obtained after 3 to 4 core samplings from individual bales and dried in kitchen microwaves (Sunbeam Digital Microwave Oven; Sunbeam Products Inc., Boca Raton, FL) with the resulting DM used to adjust the daily proportion (i.e., $70 \%$ of diet DM) of the forage component of the ration in the as-fed diet. However, due to variation in intake of forage and concentrate throughout the experiment, the actual forage-to-concentrate ratio averaged 69:39 (DM basis). Before each feeding, nonchopped, mixed-mostly grass hay was placed into 121-L capacity trashcans (Rubbermaid Commercial Products, Saratoga Springs, NY), weighed on a portable digital ground scale (Rubbermaid Pelouze Digital Receiving Scale) with 0.1-kg readability, and offered to the cows after each milking. The energy and protein supplements, as well as the minerals and vitamins premix, were mixed twice a week using an electric horizontal paddle mixer (Marion 
Table 2. Ingredient and nutrient composition (\% of DM, unless otherwise noted) of the concentrate mixes fed to lactating dairy cows

\begin{tabular}{|c|c|c|c|c|}
\hline \multirow[b]{2}{*}{ Item } & \multicolumn{4}{|c|}{ Concentrate mixes } \\
\hline & Corn-soy & Corn-flax & Molasses-soy & Molasses-flax \\
\hline \multicolumn{5}{|c|}{ Ingredient composition, $\%$ of diet DM } \\
\hline Corn meal & 12.00 & 12.00 & 0.00 & 0.00 \\
\hline Flaxseed meal & 0.00 & 16.00 & 0.00 & 16.00 \\
\hline Soybean meal & 11.00 & 0.00 & 11.00 & 0.00 \\
\hline Sunflower meal & 5.00 & 0.00 & 5.00 & 0.00 \\
\hline Liquid molasses & 0.00 & 0.00 & 12.00 & 12.00 \\
\hline Minerals and vitamin premix ${ }^{1}$ & 2.00 & 2.00 & 2.00 & 2.00 \\
\hline \multicolumn{5}{|l|}{ Nutrient composition } \\
\hline DM, $\%$ of fresh matter & 94.79 & 92.92 & 87.57 & 86.65 \\
\hline $\mathrm{CP}$ & 27.11 & 24.98 & 25.13 & 23.68 \\
\hline $\mathrm{NDF}$ & 13.99 & 17.22 & 13.30 & 14.66 \\
\hline $\mathrm{ADF}$ & 7.97 & 8.92 & 6.79 & 8.50 \\
\hline NDIN & 0.60 & 0.30 & 0.39 & 0.24 \\
\hline ADIN & 0.14 & 0.10 & 0.048 & 0.072 \\
\hline Crude fat & 5.19 & 1.88 & 5.31 & 1.89 \\
\hline Ash & 7.71 & 6.76 & 6.88 & 8.18 \\
\hline Lignin & 3.89 & 3.33 & 2.72 & 2.27 \\
\hline Starch & 31.14 & 31.71 & 4.22 & 5.60 \\
\hline Arabinose & 2.29 & 2.91 & 2.32 & 3.56 \\
\hline Xylose & 2.89 & 4.23 & 3.02 & 5.21 \\
\hline Fructose & 0.16 & 0.04 & 6.79 & 6.40 \\
\hline Glucose & 0.04 & 0.03 & 4.62 & 4.98 \\
\hline Sucrose & 5.33 & 2.04 & 16.45 & 13.71 \\
\hline Maltose & $\mathrm{ND}^{2}$ & ND & ND & ND \\
\hline Raffinose & 0.51 & 1.04 & 0.57 & 1.10 \\
\hline Stachyose & 2.30 & $\mathrm{ND}$ & 2.12 & ND \\
\hline Mannitol & ND & ND & 0.16 & 0.14 \\
\hline Total sugars ${ }^{3}$ & 13.52 & 10.29 & 36.10 & 35.09 \\
\hline $\mathrm{Ca}$ & 1.13 & 1.23 & 1.41 & 1.46 \\
\hline $\mathrm{P}$ & 0.58 & 0.58 & 0.49 & 0.50 \\
\hline $\mathrm{Mg}$ & 0.76 & 0.87 & 0.74 & 0.87 \\
\hline $\mathrm{K}$ & 1.29 & 0.83 & 2.67 & 2.22 \\
\hline $\mathrm{S}$ & 0.28 & 0.28 & 0.47 & 0.46 \\
\hline $\mathrm{Na}$ & 0.89 & 0.80 & 0.81 & 0.81 \\
\hline $\mathrm{Cl}$ & 0.01 & 0.01 & 0.54 & 0.50 \\
\hline $\mathrm{Fe}, \mathrm{mg} / \mathrm{kg}$ & 535.0 & 443.3 & 605.0 & 589.5 \\
\hline $\mathrm{Cu}, \mathrm{mg} / \mathrm{kg}$ & 116.5 & 96.50 & 90.75 & 97.50 \\
\hline $\mathrm{Mn}, \mathrm{mg} / \mathrm{kg}$ & 362.3 & 323.8 & 287.0 & 351.0 \\
\hline $\mathrm{Zn}, \mathrm{mg} / \mathrm{kg}$ & 453.0 & 387.8 & 372.8 & 436.0 \\
\hline
\end{tabular}

Mixer; Rapids Machinery Co., Marion, IA) to yield the individual concentrate mixes fed in this experiment. Each concentrate mix was stored in 121-L Rubbermaid trashcans with daily amounts weighed before each feeding on the same portable digital ground scale used for the grass hay. The concentrate mixes were top-dressed on the grass hay with rations fed twice daily at approximately 0630 and $1630 \mathrm{~h}$. The amount of feed offered to the cows was adjusted daily to yield orts equal to approximately 5 to $10 \%$ of DMI. Orts were collected daily before the a.m. feeding and weighed as done for the hay and concentrate mixes. Feed intake was recorded by subtracting the amount of feed offered daily from the amount of orts. The electronic recognition Calan doors system (American Calan Inc.) was used to individualize the dietary treatments offered to the cows. Feed efficiency was computed by dividing mean milk yield by mean DMI, and apparent efficiency of utilization of feed $\mathrm{N}$ was calculated by dividing mean milk $\mathrm{N}$ output (milk $\mathrm{N}$ concentration $\times$ milk yield) by mean $\mathrm{N}$ intake. Body weights were recorded at the same time for 3 consecutive days before the beginning of the experiment. Animals had free access to water throughout the duration of the experiment.

During each 5-d-long sampling week, individual hay samples were collected daily as described earlier and 


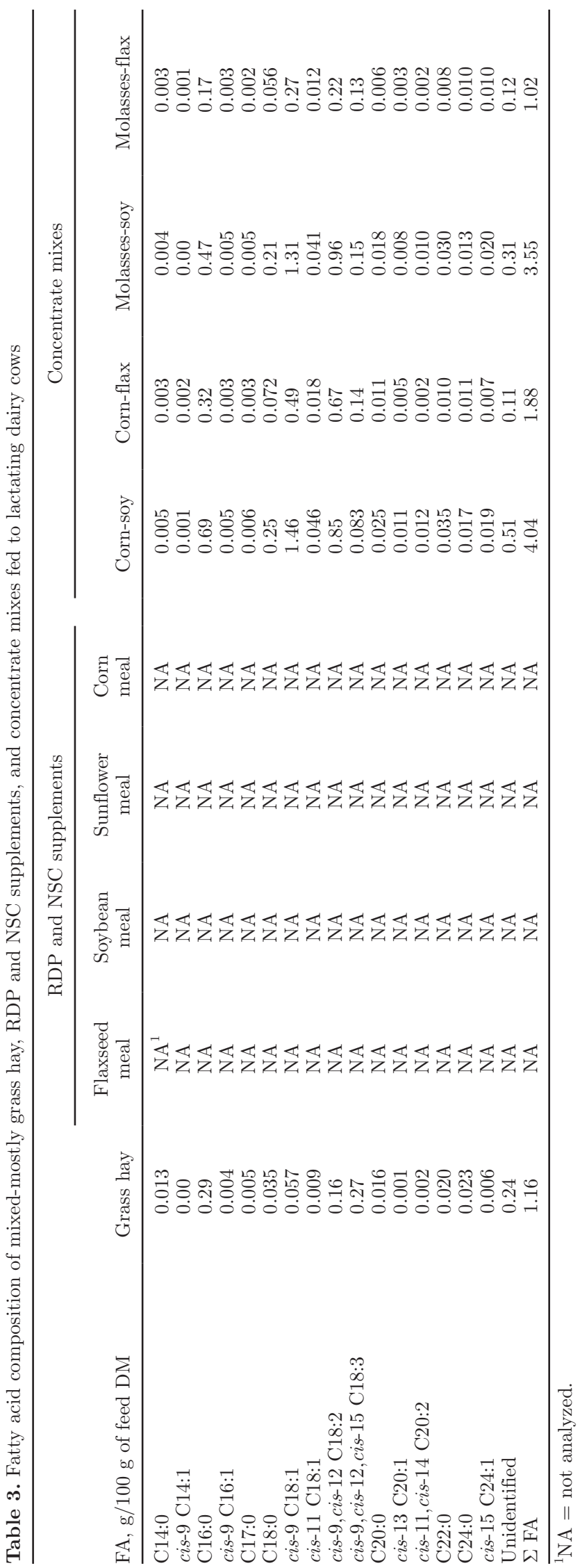

then divided into 2 equal size (about $150 \mathrm{~g}$ each) subsamples. The first subsample was used for adjusting the dietary proportion of forage DM and the second subsample was used to yield weekly composites by mixing equal amounts of hay DM from individual subsamples. Samples of individual feedstuffs, concentrate mixes, and orts were collected once every week during the adaptation phase (wk 1 and 2), and daily during the 5 sampling days (d 15 to 19 of each experimental period). Daily samples of feeds, concentrate mixes, and orts (by cow/diet) collected during the sampling days were composited by period.

Liquid molasses was analyzed for all nutrients reported below with the exception of NDF, ADF, NDIN, ADIN, crude fat, and ash. All remaining feeds (i.e., mixed-mostly grass hay, corn meal, flaxseed meal, soybean meal, and sunflower meal), concentrate mixes, and orts were dried in a forced air oven at $55^{\circ} \mathrm{C}$ for 48 h (VWR Scientific, Radnor, PA), ground through a 1-mm screen in a Wiley mill (Arthur H. Thomas, Philadelphia, PA), and sent to a commercial laboratory (Analab; Agri-King Inc., Fulton, IL) for analytical DM (method 930.15; AOAC International, 2006), total N using a combustion method (Leco TruMac N Macro Determinator; Leco Corp., St. Joseph, MI), NDF [Ankom Technology method 6 (NDF in feeds-filter bag technique for A200; Ankom Technology, Fairport, NY); solutions as in Van Soest et al., 1991], ADF [Ankom Technology method 5 (ADF in feeds-filter bag technique for A200; Ankom Technology); solutions as in AOAC International (1998) method 973.18], and ash (method 942.05; AOAC International, 2006). All feeds and concentrate mixes were also analyzed for crude fat (method 2003.05; AOAC International, 2006), NDIN (Leco TruMac N Macro Determinator on NDF residue), ADIN (Leco TruMac N Macro Determinator on ADF residue), starch (enzymatically and colorimetrically with a Smartchem Discrete Analyzer using a glucose oxidase/ peroxidase method; kit code no. 0410, 0618, 0590; Amresco, Solon, $\mathrm{OH}$ ), individual sugars (arabinose, xylose, fructose, glucose, sucrose, maltose, raffinose, stachyose, and mannitol using a Beckman HPLC (Beckman Coulter Inc., Fullerton, CA) equipped with an evaporative light scattering detection system), individual minerals (Ca, P, Mg, K, S, Na, Cl, Fe, Cu, Mn, and $\mathrm{Zn}$ ) via inductively coupled plasma mass spectrophotometry using a Varian Vista MPX ICP [Agilent Technologies, Santa Clara, CA; equipped with microwave digestion; AOAC International (1998) method 985.01], and acidinsoluble ash (combustion of ADF residue in a muffle furnace at $500^{\circ} \mathrm{C}$ overnight). Grass hay and concentrate mixes were additionally analyzed for individual FA (Kevin Harvatine's Laboratory; Penn State University, University Park, PA) by GC after direct methylation 
(Sukhija and Palmquist, 1988). Flaxseed meal, soybean meal, sunflower meal, and mixed-mostly grass hay samples were extracted and analyzed for SDG according to the procedures described by Muir and Westcott (2000).

\section{Milk Sampling and Analyses}

Cows were milked twice daily at approximately 0430 and $1500 \mathrm{~h}$, and milk yield was recorded at each milking throughout the experiment. Milk samples were collected for 3 consecutive days (d 15, 16, and 17) in each experimental period during a.m. and p.m. milkings, preserved in tubes containing 2-bromo-2-nitropropan-1,3 diol, pooled by cow according to a.m. and p.m. milk weights, and refrigerated at $4^{\circ} \mathrm{C}$ until shipped for determination of fat, protein, lactose, and MUN by mid-infrared reflectance spectroscopy (Dairy One Cooperative Inc., Ithaca, NY). Milk samples without preservative were collected and pooled using the same procedure and stored at $-80^{\circ} \mathrm{C}$ until analyzed for milk FA profile. Milk samples used for extraction of FA were prepared and methylated according to method 996.06 (AOAC International, 1998) with analysis conducted at the Agriculture and Agri-Food Canada-Dairy and Swine Research and Development Centre (Sherbrooke, QC, Canada) using GLC as reported by Petit and Côrtes (2010). Lignans in milk were hydrolyzed and extracted according to the procedures described by Gagnon et al. (2009). Only enterolactone was analyzed in milk because previous research (Petit and Gagnon, 2009) showed no detectable concentration of enterodiol in milk, and enterolactone is the major SDG metabolite produced in the rumen (Côrtes et al., 2008), possibly because enterodiol is further oxidized to enterolactone by the gut microbiome (Borriello et al., 1985). Milk enterolactone was analyzed colorimetrically $(\mathrm{UV} / \mathrm{V}$ is colorimetric spectrophotometer; Beckman Coulter Inc., Brea, CA) using a commercial enzymatic immunoassay (assay kit no. 500520; Cayman Chemical Co., Ann Arbor, MI).

\section{Blood Sampling and Analyses}

Blood samples were collected from the coccygeal vein into empty Vacutainer tubes (Becton Dickinson, Franklin Lakes, NJ) once daily for 2 consecutive days (d 18 and 19) at approximately $1200 \mathrm{~h}$. After sampling, tubes were kept on ice and immediately transported to the laboratory for processing. Samples were centrifuged $\left(3,300 \times g, 20 \mathrm{~min}, 4^{\circ} \mathrm{C}\right)$ and plasma was collected and stored at $-80^{\circ} \mathrm{C}$ for later analyses. Plasma urea N (PUN; diacetyl-monoxime method), SOD (assay kit no. 706002; Cayman Chemical Co.), and GPx (assay kit no. 703102; Cayman Chemical Co.) were all analyzed colorimetrically using a UV/Vis colorimetric spectrophotometer.

\section{Digestive Tract and Urinary Sampling and Analyses}

Fecal grab samples were collected from all 16 cows once a day for 3 consecutive days (d 16, 17, and 18) at 0700,1200 , and $1700 \mathrm{~h}$ by stimulating defecation or collected directly from the rectum. Samples were pooled by cow based on fresh weight (about $200 \mathrm{~g} /$ sampling) over the $3 \mathrm{~d}$ to obtain a single composite and then frozen at $-20^{\circ} \mathrm{C}$. At the end of each sampling week, composite fecal samples were thawed and placed in aluminum trays in a forced-air oven at $55^{\circ} \mathrm{C}$ until completely dried (approximately $72 \mathrm{~h}$ ). Dried samples were ground to pass through a $1-\mathrm{mm}$ screen (Wiley mill) and analyzed for analytical DM, ash, total N, NDF, ADF, and acid-insoluble ash as described previously. Acid-insoluble ash was used as an internal marker to estimate fecal output of DM (Van Keulen and Young, 1977; Cochran et al., 1986).

Spot urine samples were taken once daily for 3 consecutive days (d 16, 17, and 18) at 0800, 1200, and 1500 $\mathrm{h}$ by stimulation of the pudendal nerve massaging the area below the vulva. Immediately following each sampling, urine samples were combined with $400 \mu \mathrm{L}$ of 6 $N \mathrm{HCl}$, pooled by cow on a volume basis, and stored in 3 separate $50-\mathrm{mL}$ centrifuge tubes at $-20^{\circ} \mathrm{C}$ until analyses. After thawing at room temperature, urinary samples were analyzed colorimetrically for creatinine (assay kit no. 500701; Cayman Chemical Co.), allantoin (Chen et al., 1992), uric acid (assay kit no. 1045-225; Stanbio Laboratory, Boerne, TX), and total N (microKjeldahl analysis; AOAC, 1990; Dairy One Cooperative Inc.). Daily urinary volume and excretion of total $\mathrm{N}$ were estimated from urinary creatinine concentration assuming a constant creatinine excretion rate of $29 \mathrm{mg} / \mathrm{kg}$ of BW (Valadares et al., 1999). Urinary excretion of purine derivatives $(\mathbf{P D}=$ allantoin plus uric acid $)$ was calculated based on the creatinine to PD ratio (Chizzotti et al., 2008) also assuming a constant creatinine excretion rate of $29 \mathrm{mg} / \mathrm{kg}$ of BW (Valadares et al., 1999).

\section{Statistical Analyses}

Data were analyzed using the MIXED procedure of SAS (version 9.3; SAS Institute Inc., Cary, NC) according to a replicated $4 \times 4$ Latin square design with a 2 $\times 2$ factorial arrangement of treatments. The following model was fitted for all variables:

$$
\begin{gathered}
\mathrm{Y}_{\mathrm{ijklm}}=\mu+\mathrm{S}_{\mathrm{i}}+\mathrm{P}_{\mathrm{j}}+\mathrm{C}_{\mathrm{k}(\mathrm{i})}+\mathrm{NSC}_{\mathrm{l}}+\mathrm{RDP}_{\mathrm{m}}+\mathrm{NSC} \\
\times \mathrm{RDP}_{\mathrm{lm}}+\mathrm{S} \times \mathrm{NSC}_{\mathrm{il}}+\mathrm{S} \times \mathrm{RDP}_{\mathrm{im}}+\mathrm{E}_{\mathrm{ijklm}},
\end{gathered}
$$


where $Y_{i j k l m}=$ dependent variable, $\mu=$ overall mean, $S_{i}$ $=$ fixed effect of ith square, $\mathrm{P}_{\mathrm{j}}=$ fixed effect of $\mathrm{jth}$ period, $\mathrm{C}_{\mathrm{k}(\mathrm{i})}=$ random effect of kth cow within ith square, $\mathrm{NSC}_{1}=$ fixed effect of lth NSC supplement (corn meal or liquid molasses), $\mathrm{RDP}_{\mathrm{m}}=$ fixed effect of mth $\mathrm{RDP}$ supplement (protein mix or flaxseed meal), NSC $\times$ $\mathrm{RDP}_{\mathrm{lm}}=$ interaction between lth NSC supplement and mth RDP supplement, $\mathrm{S} \times \mathrm{NSC}_{\mathrm{il}}=$ interaction between ith square and lth NSC supplement, $\mathrm{S} \times \mathrm{RDP}_{\mathrm{im}}=$ interaction between ith square and mth RDP supplement, and $\mathrm{E}_{\mathrm{ijk} k \mathrm{~m}}=$ error term $\sim N\left(0, \sigma_{e}^{2}\right)$. All reported values are LSM. Trends were declared at $0.05<P \leq 0.10$. Interaction terms were removed from the final model when $P \geq 0.25$.

\section{RESULTS AND DISCUSSION}

\section{NSC Supplement Effects}

No effect of NSC supplements was observed for both DMI and milk yield (Table 4$)$. However, $4 \%$ FCM $(-0.70$ $\mathrm{kg} / \mathrm{d} ; P=0.03)$ and ECM $(-0.60 \mathrm{~kg} / \mathrm{d} ; P=0.04)$ were both lowest in cows fed the liquid molasses-based diets because of decreased $(P=0.06)$ concentration of milk fat (Table 4$)$. Decreased yield of milk fat $(P=0.02)$ in cows fed the liquid molasses-based diets is explained by reduced $(P=0.06)$ concentration of milk fat (Table 4$)$. Yield (data not shown) and proportion of milk trans-10 C18:1 were reduced significantly in cows fed the liquid molasses-based diets, but no effect of NSC supplements was observed for yield (data not shown) and proportion of milk trans-10,cis-12 CLA, which is known to inhibit milk fat synthesis in the mammary gland (Baumgard et al., 2000, 2001). Although Lock et al. (2007) showed evidence that the trans-10 C18:1 isomer was not directly involved in milk fat depression, Shingfield et al. (2009) concluded that trans-10 18:1 does possess antilipogenic activity and may have contributed to the reduction in milk fat synthesis during diet-induced milk fat depression in dairy cows. Therefore, it is possible that other FA such as cis-10,trans-12 CLA and trans-9,cis-11 CLA (Shingfield et al., 2009) or dilution of dietary energy due to the higher concentration of ash in molasses compared with corn (NRC, 2001) may explain the reductions in milk fat yield $(-4.9 \%), 4 \%$ FCM $(-4.7 \%)$, and ECM $(-3.8 \%)$ in cows fed MOL and MOL $+\mathrm{FX}$ diets. In addition, the mean proportion of added sugars (i.e., $7.5 \%$ of the diet DM) from liquid molasses-based diets was above the recommended level of added sugars (i.e., 2.5 to $5.0 \%$ of the diet DM), according to Firkins (2010), and may have contributed with the reduced animal production when feeding MOL and MOL+FX.
A significant NSC $\times$ RDP supplement interaction was observed for MUN, with cows fed diets containing flaxseed meal showing the lowest $(\mathrm{MOL}+\mathrm{FX}=$ $14.9 \mathrm{mg} / \mathrm{dL})$ and highest $(\mathrm{CM}+\mathrm{FX}=17.4 \mathrm{mg} / \mathrm{dL})$ concentrations of MUN (Table 4). Thus, it can be hypothesized that the higher fermentation rate of sucrose versus starch (Chamberlain et al., 1993) led to a more balanced supply of molasses NSC and flaxseed meal RDP, ultimately reducing $\mathrm{NH}_{3}$ formation in the rumen (Sannes et al., 2002; Broderick et al., 2008; Oelker et al., 2009). The concentration $(P<0.01)$ and yield $(P$ $=0.01$ ) of milk enterolactone were both highest in cows fed the liquid molasses-based diets (Table 4). As shown in Table 1, the concentration of SDG was below the level of detection in grass hay, soybean meal, and sunflower meal. However, other plant lignans such as matairesinol, pinoresinol, and lariciresinol are also converted into mammalian lignans (Heinonen et al., 2001), with pinoresinol and lariciresinol present in higher concentrations than SDG and matairesinol in many plants (Milder et al., 2005). It is unlikely that molasses would contribute a significant amount of lignans that could explain the observed increase in milk enterolactone. In fact, the concentrations of the plant lignans secoisolariciresinol and matairesinol averaged, respectively, 1.5 and $0.9 \mathrm{mg} / \mathrm{kg}$ of DM in a concentrate containing $4 \%$ sugarcane molasses (Steinshamn et al., 2008) with no secoisolariciresinol and matairesinol detected in concentrates containing 1 to $5 \%$ sugar beet molasses (Höjer et al., 2012). Therefore, compared with corn meal, liquid molasses may select for ruminal microorganisms with greater capacity to convert plant lignans to enterolactone.

A significant NSC $\times$ RDP supplement interaction was observed for milk $\mathrm{N}$ efficiency, with cows fed MOL+FX showing the lowest value (Table 4). Cows fed MOL+FX showed the highest $\mathrm{N}$ intake and lowest milk $\mathrm{N}$ yield (Tables 4), thus explaining the lowest milk N efficiency. The concentration of PUN was lowest $(P=0.02)$ in cows fed the liquid molasses-based diets (Table 4). Intake of $\mathrm{N}$ was not affected by the NSC supplements $(P$ $=0.40$; Table 4 ), suggesting that decreased PUN was caused by other factors. Replacing starch with incremental dietary levels of sucrose linearly reduced the concentration of ruminal $\mathrm{NH}_{3}$ (Broderick et al., 2008). Hristov et al. (2005) showed that the concentration of ruminal $\mathrm{NH}_{3}$ was reduced via decreased $\mathrm{NH}_{3}$ production or increased $\mathrm{NH}_{3}$ uptake for microbial protein synthesis in dairy cows provided with intraruminal doses (20\% of dietary DMI) of corn dextrose or corn starch, respectively. Because urinary excretion of $\mathrm{PD}$ was not affected by NSC or RDP supplements (Table 4), it is conceivable that reduced PUN was caused by decreased $\mathrm{NH}_{3}$ production in cows fed MOL and MOL+FX. 
Table 4. Least squares means for DMI, milk yield, concentrations and yields of milk components, plasma concentrations of urea N (PUN) and antioxidant enzymes, apparent total-tract nutrient digestibility, and urinary $\mathrm{N}$ excretion in lactating dairy cows fed mixed-mostly grass hay and different NSC and RDP supplements

\begin{tabular}{|c|c|c|c|c|c|c|c|c|}
\hline \multirow[b]{2}{*}{ Item } & \multicolumn{4}{|c|}{ Diet $^{1}$} & \multirow[b]{2}{*}{ SEM } & \multicolumn{3}{|c|}{$P$-value ${ }^{2}$} \\
\hline & $\mathrm{CM}$ & $\mathrm{CM}+\mathrm{FX}$ & MOL & $\mathrm{MOL}+\mathrm{FX}$ & & NSC & $\mathrm{RDP}$ & $\begin{array}{c}\text { NSC } \\
\times \text { RDP }\end{array}$ \\
\hline Concentrate DMI, $\mathrm{kg} / \mathrm{d}$ & 4.87 & 4.96 & 4.83 & 5.05 & 0.15 & 0.83 & 0.12 & 0.52 \\
\hline Total DMI, kg/d & 15.58 & 15.67 & 15.59 & 16.28 & 0.57 & 0.45 & 0.34 & 0.46 \\
\hline Total N intake, $\mathrm{g} / \mathrm{d}$ & 409.3 & 396.3 & 391.5 & 397.4 & 13.74 & 0.40 & 0.70 & 0.32 \\
\hline $\mathrm{ECM},{ }^{4} \mathrm{~kg} / \mathrm{d}$ & 16.24 & 15.10 & 16.14 & 13.98 & 0.53 & 0.04 & $<0.001$ & 0.09 \\
\hline Milk fat, $\%$ & 4.67 & 4.53 & 4.56 & 4.31 & 0.15 & 0.06 & 0.03 & 0.55 \\
\hline Milk fat, $\mathrm{kg} / \mathrm{d}$ & 0.64 & 0.58 & 0.63 & 0.52 & 0.02 & 0.02 & $<0.001$ & 0.10 \\
\hline Milk protein, \% & 3.35 & 3.53 & 3.39 & 3.54 & 0.06 & 0.39 & $<0.001$ & 0.62 \\
\hline Milk protein, $\mathrm{kg} / \mathrm{d}$ & 0.47 & 0.46 & 0.47 & 0.44 & 0.02 & 0.49 & 0.03 & 0.15 \\
\hline Milk lactose, \% & 4.74 & 4.72 & 4.77 & 4.71 & 0.03 & 0.60 & 0.01 & 0.10 \\
\hline Milk lactose, $\mathrm{kg} / \mathrm{d}$ & 0.66 & 0.61 & 0.66 & 0.58 & 0.03 & 0.33 & $<0.001$ & 0.13 \\
\hline PUN, mg/dL & 20.92 & 19.36 & 19.21 & 18.70 & 0.56 & 0.02 & 0.05 & 0.30 \\
\hline Plasma SOD ${ }^{5} \mathrm{nmol} / \mathrm{min}$ per $\mathrm{mg}$ of protein & 4.27 & 4.00 & 4.18 & 4.69 & 0.28 & 0.24 & 0.63 & 0.13 \\
\hline Plasma GPx,${ }^{6} \mathrm{nmol} / \mathrm{min}$ per $\mathrm{mL}$ & 56.27 & 52.52 & 54.81 & 57.70 & 3.30 & 0.54 & 0.89 & 0.30 \\
\hline OM digestibility, $\%$ of OM intake & 63.01 & 63.39 & 63.45 & 63.44 & 0.64 & 0.67 & 0.75 & 0.73 \\
\hline NDF digestibility, $\%$ of NDF intake & 44.55 & 45.63 & 44.85 & 45.54 & 0.95 & 0.91 & 0.33 & 0.83 \\
\hline $\mathrm{ADF}$ digestibility, $\%$ of $\mathrm{ADF}$ intake & 31.14 & 30.49 & 31.68 & 30.66 & 1.26 & 0.77 & 0.50 & 0.88 \\
\hline $\mathrm{N}$ digestibility, $\%$ of $\mathrm{N}$ intake & 64.21 & 64.46 & 61.41 & 61.13 & 0.93 & $<0.001$ & 0.99 & 0.76 \\
\hline Urinary allantoin, mmol/d & 134.0 & 141.0 & 119.9 & 137.2 & 12.99 & 0.39 & 0.29 & 0.70 \\
\hline Urinary uric acid, $\mathrm{mmol} / \mathrm{d}$ & 8.01 & 9.47 & 8.25 & 6.70 & 0.98 & 0.16 & 0.93 & 0.11 \\
\hline Urinary purine derivatives, ${ }^{7} \mathrm{mmol} / \mathrm{d}$ & 142.1 & 150.5 & 128.1 & 143.8 & 13.62 & 0.35 & 0.32 & 0.82 \\
\hline Urinary $\mathrm{N}$ excretion, $\mathrm{g} / \mathrm{d}$ & 175.4 & 167.3 & 145.2 & 156.9 & 10.48 & 0.04 & 0.93 & 0.32 \\
\hline Urinary $\mathrm{N}$ excretion, $\%$ of $\mathrm{N}$ intake & 42.44 & 42.64 & 36.73 & 38.70 & 2.15 & 0.02 & 0.66 & 0.67 \\
\hline
\end{tabular}

${ }^{1} \mathrm{CM}=$ corn meal plus soybean meal-sunflower meal protein mix; $\mathrm{CM}+\mathrm{FX}=$ corn meal plus flaxseed meal; MOL $=$ liquid molasses plus soybean meal-sunflower meal protein mix; MOL $+\mathrm{FX}=$ liquid molasses plus flaxseed meal.

${ }^{2}$ Probability of NSC main effect (CM plus $\mathrm{CM}+\mathrm{FX}$ vs. MOL plus MOL+FX); probability of RDP main effect (CM plus MOL vs. CM+FX plus MOL $+\mathrm{FX})$; probability of NSC $\times$ RDP supplement interaction; significance was declared at $P \leq 0.05$ and trends at $0.05<P \leq 0.10$.

${ }^{3} 4 \% \mathrm{FCM}=[0.40 \times$ milk yield $(\mathrm{kg} / \mathrm{d})]+[15 \times$ milk fat yield $(\mathrm{kg} / \mathrm{d})]$ (Gaines and Davidson, 1923).

${ }^{4} \mathrm{ECM}=[0.327 \times$ milk yield $(\mathrm{kg} / \mathrm{d})]+[12.95 \times$ fat yield $(\mathrm{kg} / \mathrm{d})]+[7.2 \times$ protein yield $(\mathrm{kg} / \mathrm{d})]($ Orth, 1992).

${ }^{5} \mathrm{SOD}=$ superoxide dismutase.

${ }^{6} \mathrm{GPx}=$ glutathione peroxidase.

${ }^{7}$ Calculated based on the creatinine to purine derivative (PD) ratio (Chizzotti et al., 2008) assuming a constant creatinine excretion rate of 29 $\mathrm{mg} / \mathrm{kg}$ of BW (Valadares et al., 1999).

Except for the apparent total-tract digestibility of $\mathrm{N}$, which was reduced $(P<0.001)$ with feeding liquid molasses, no additional NSC supplement effects were observed for OM, NDF, and ADF digestibilities (Table 4). Concentration of ruminal $\mathrm{NH}_{3}-\mathrm{N}$ has been shown to decrease as a result of sucrose or molasses being supplemented as substitutes for starch or corn (Sannes et al., 2002; Broderick et al., 2008; Oelker et al., 2009). In addition to increased efficiency of $\mathrm{NH}_{3}-\mathrm{N}$ utilization by ruminal microbes, reduced $\mathrm{NH}_{3}-\mathrm{N}$ concentration in the rumen may be indicative of decreased proteolysis, which can reduce $\mathrm{N}$ digestibility in the rumen. In fact, apparent $\mathrm{N}$ digestibility in the rumen was linearly reduced when sucrose increased from 0 to $7.5 \%$ of diet
DM (Broderick et al., 2008). Although excretion of PD was not affected by the NSC supplements, urinary excretion of $\mathrm{N}$, expressed in grams per day or as a percentage of $\mathrm{N}$ intake, was lowest in cows fed liquid molasses (Table 4). Reduced urinary $\mathrm{N}$ excretion with feeding liquid molasses coincided with increased fecal $\mathrm{N}$ excretion, indicating a shift in $\mathrm{N}$ partitioning from urine to feces. It is noteworthy, however, that urinary $\mathrm{N}$ and PD excretion results from the current study should be interpreted cautiously because urinary creatinine excretion, which was used as an internal marker to estimate urinary volume, is assumed to be excreted at a rate in constant proportion to BW (Valadares et al., 1999). 
Table 5. Least squares means for milk proportions (\% of total milk FA) of SFA in lactating dairy cows fed mixed-mostly grass hay and different NSC and RDP supplements

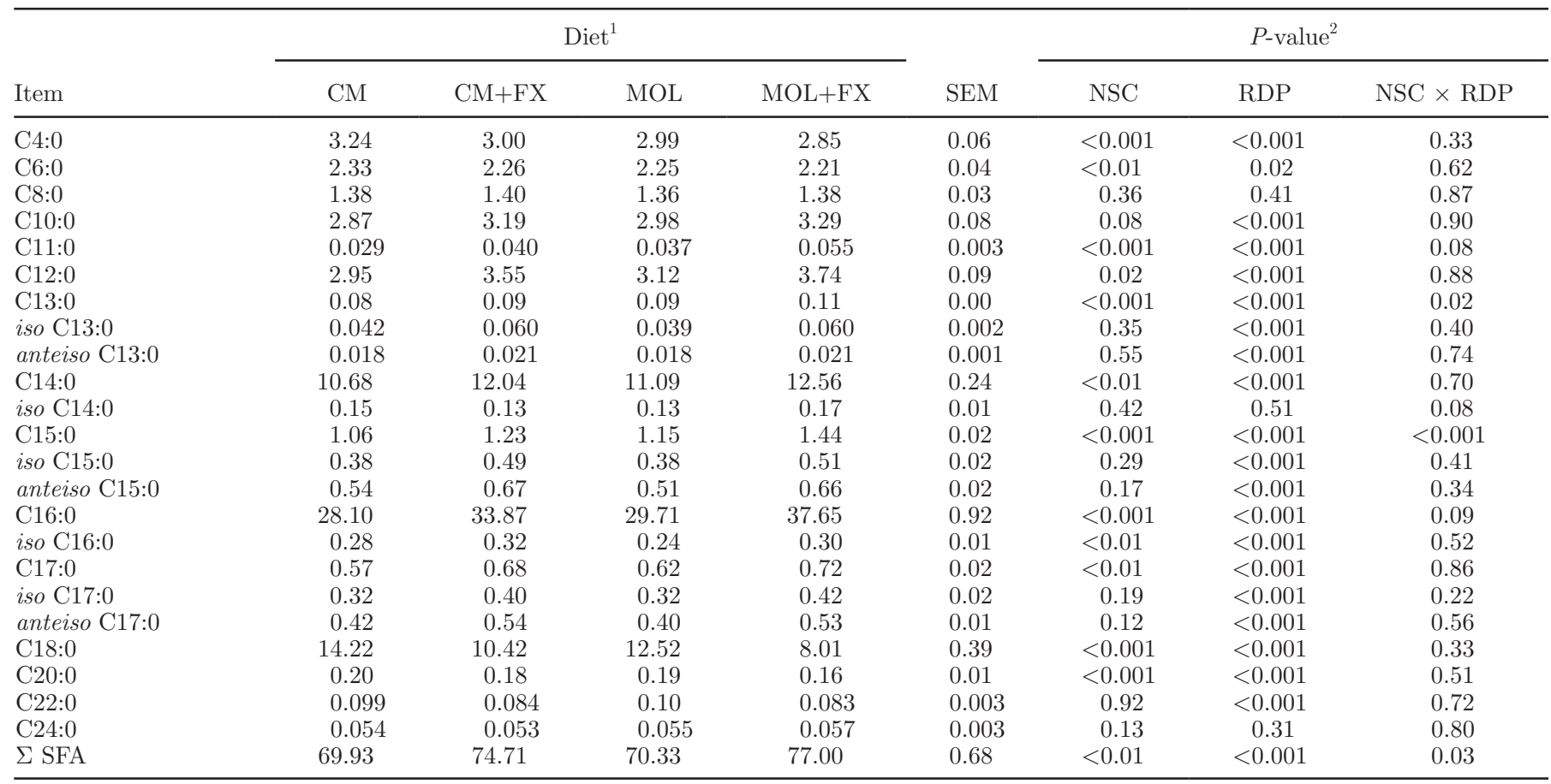

${ }^{1} \mathrm{CM}=$ corn meal plus soybean meal-sunflower meal protein mix; $\mathrm{CM}+\mathrm{FX}=$ corn meal plus flaxseed meal; MOL = liquid molasses plus soybean meal-sunflower meal protein mix; MOL+FX = liquid molasses plus flaxseed meal.

${ }^{2}$ Probability of NSC main effect (CM plus $\mathrm{CM}+\mathrm{FX}$ vs. MOL plus MOL+FX); probability of RDP main effect (CM plus MOL vs. CM+FX plus MOL+FX); probability of NSC $\times$ RDP supplement interaction; significance was declared at $P \leq 0.05$ and trends at $0.05<P \leq 0.10$.

Significant NSC $\times$ RDP supplement interactions were observed for the milk proportions of C13:0, C15:0, and total SFA, with cows fed the MOL+FX diet showing the highest values (Table 5), likely as a result of enhanced de novo synthesis of short- and medium-chain FA with feeding liquid molasses and flaxseed meal as discussed in greater detail below. Although the milk proportions of C11:0, C12:0, C14:0, C16:0, and C17:0 were increased $(P<0.01)$, those of $\mathrm{C} 4: 0, \mathrm{C} 6: 0$, iso C16:0, C18:0, and C20:0 were decreased $(P<0.01)$ when feeding the liquid molasses-based diets (Table 5). Intake of C18:0 was lowest $(P<0.001 ;-11 \%$; data not shown) in cows fed liquid molasses explaining, at least partly, the decrease in milk C18:0. However, despite the lowest intake of $\mathrm{C} 16: 0(P<0.001 ;-13 \%$; data not shown) when feeding MOL and MOL+FX, the milk proportion of C16:0 was highest. Rotta et al. (2014) also observed a decoupled response between C16:0 intake and muscle proportion of C16:0. Therefore, these results appear to indicate that sucrose stimulates de novo synthesis of medium-chain FA, as suggested by Martel et al. (2011).

Significant NSC $\times$ RDP supplement interactions were observed for the milk proportions of cis-9 C18:1, cis-11 C18:1, cis-9,cis-12 C18:2, and cis-11 C20:1, the sums of cis configuration FA, n-6 FA, MUFA, and PUFA, and the n- 6 to $\mathrm{n}-3$ ratio, with cows fed MOL $+\mathrm{FX}$ showing the lowest values (Table 6). Overall, reduced FA intake (data not shown) and more efficient ruminal biohydrogenation reactions might explain these interactions. For instance, a significant NSC $\times$ RDP interaction was observed for intake of cis-9,cis-12 C18:2, with the lowest value (i.e., $32.9 \mathrm{~g} / \mathrm{d}$ ) observed in cows fed MOL+FX (data not shown). Because cis-9,cis-12 C18:2 is isomerized to cis-9,trans-11 CLA and then reduced to trans-11 C18:1 during ruminal biohydrogenation (Harfoot, 1981), the lowest level of cis-9,cis-12 C18:2 in milk fat of cows fed MOL+FX is indicative of more complete isomerization and hydrogenation reactions.

Out of the 30 cis configuration unsaturated FA obtained in milk fat, 7 were increased and 3 decreased $(P \leq 0.05)$ with feeding liquid molasses (Table 6). Indices of stearoyl-CoA desaturase (also known as $\Delta^{9}$ desaturase; EC 1.14.19.1) were not affected by the NSC supplements (Table 6), suggesting that the increased milk proportions of cis-9 $\mathrm{C} 16: 1$, cis-11 C16:1, cis-13 C16:1, and cis-9 C17:1 were explained by their uptake by the mammary gland. Intake of cis-9,cis-12, cis- 15 C18:3 tended to increase $(P=0.07$; data not shown $)$ with feeding liquid molasses and explains, at least in 
Table 6. Least squares means for milk proportions (\% of total milk FA) of unsaturated FA and $\Delta^{9}$-desaturase indices in lactating dairy cows fed mixed-mostly grass hay and different NSC and RDP supplements

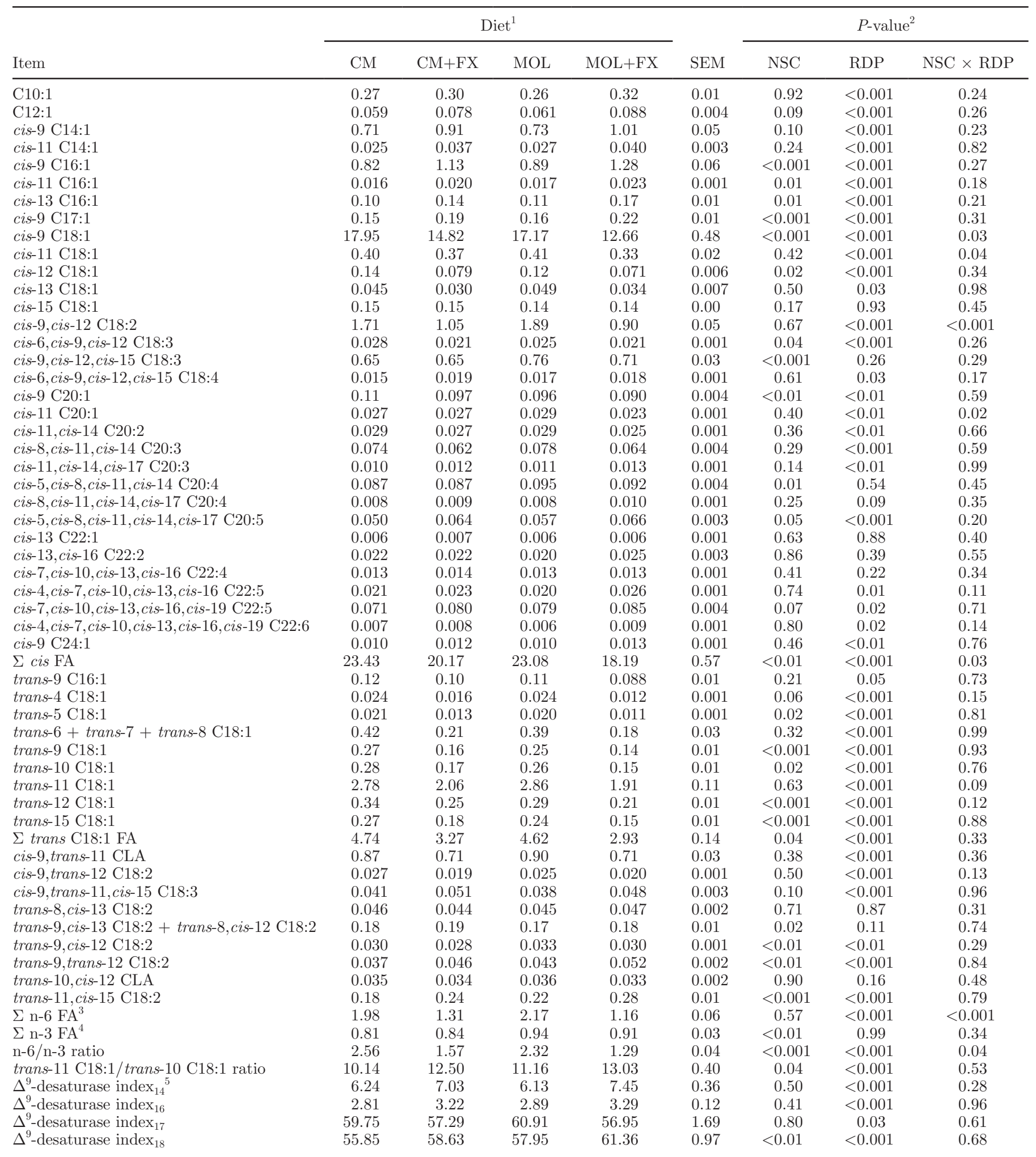


Table 6 (Continued). Least squares means for milk proportions ( $\%$ of total milk FA) of unsaturated FA and $\Delta^{9}$-desaturase indices in lactating dairy cows fed mixed-mostly grass hay and different NSC and RDP supplements

\begin{tabular}{|c|c|c|c|c|c|c|c|c|}
\hline Item & \multicolumn{4}{|c|}{$\operatorname{Diet}^{1}$} & SEM & \multicolumn{3}{|c|}{$P$-value ${ }^{2}$} \\
\hline$\Delta^{9}$-desaturase index ${ }_{\text {cis }-9, \text { trans-11 CLA }}$ & 23.88 & 25.90 & 24.07 & 27.33 & 0.77 & 0.18 & $<0.001$ & 0.33 \\
\hline$\Sigma$ PUFA & 4.24 & 3.51 & 4.62 & 3.47 & 0.13 & 0.06 & $<0.001$ & 0.02 \\
\hline$\Sigma$ Unsaturated FA & 29.90 & 25.11 & 29.48 & 22.83 & 0.67 & $<0.01$ & $<0.001$ & 0.03 \\
\hline
\end{tabular}

${ }^{1} \mathrm{CM}=$ corn meal plus soybean meal-sunflower meal protein mix; $\mathrm{CM}+\mathrm{FX}=$ corn meal plus flaxseed meal; MOL $=$ liquid molasses plus soybean meal-sunflower meal protein mix; MOL+FX = liquid molasses plus flaxseed meal.

${ }^{2}$ Probability of NSC main effect (CM plus $\mathrm{CM}+\mathrm{FX}$ vs. MOL plus MOL $+\mathrm{FX}$ ); probability of RDP main effect (CM plus MOL vs. CM+FX plus MOL+FX); probability of NSC $\times$ RDP supplement interaction; significance was declared at $P \leq 0.05$ and trends at $0.05<P \leq 0.10$.

${ }^{3} \Sigma \mathrm{n}-6 \mathrm{FA}=$ cis-9,cis-12 C18:2 + cis-6,cis-9,cis-12 C18:3 + cis-11,cis-14 C20:2 + cis-8,cis-11,cis-14 C20:3 + cis-5,cis-8,cis-11,cis-14 C20:4 + cis-13, cis-16 C22:2 + cis-7,cis-10,cis-13,cis-16 C22:4 + cis-4,cis-7,cis-10,cis-13,cis-16 C22:5.

${ }^{4} \Sigma \mathrm{n}-3 \mathrm{FA}=$ cis-9,cis-12,cis-15 C18:3 + cis-6,cis-9,cis-12,cis-15 C18:4 + cis-11,cis-14,cis-17 C20:3 + cis-8,cis-11,cis-14,cis-17 C20:4 + cis-5,cis8,cis-11,cis-14,cis-17 C20:5 + cis-7,cis-10,cis-13,cis-16,cis-19 C22:5 + cis-4,cis-7,cis-10,cis-13,cis-16,cis-19 C22:6.

${ }^{5} \Delta^{9}$-desaturase index $_{14}=$ cis-9 $\mathrm{C} 14: 1 \times 100 \div(\mathrm{C} 14: 0+$ cis-9 $14: 1)$; a similar calculation was done for the remaining $\Delta^{9}$-desaturase indices shown in this table.

part, the increased $(P<0.001)$ milk proportion of cis9,cis-12,cis-15 C18:3. According to Bernal-Santos et al. (2010), cis-9,cis-12,cis-15 C18:3 is prone to numerous chain elongation and desaturation reactions after being absorbed in the small intestine. Thus, increased proportions of milk cis-5,cis-8,cis-11,cis-14 C20:4 ( $P$ $=0.01)$ and cis-5,cis-8,cis-11,cis-14,cis-17 C20:5 ( $P=$ $0.05)$ may be explained by enhanced intestinal flow of cis-9, cis-12,cis-15 C18:3.

Milk proportions of trans-4 C18:1 $(P=0.06)$, trans-5 C18:1 $(P=0.02)$, trans-9 C18:1 $(P<0.001)$, trans-10 C18:1 $(P=0.02)$, trans-12 C18:1 $(P<0.001)$, and trans-15 C18:1 $(P<0.001)$ as well as the sum of trans C18:1 FA $(P=0.04)$ were all decreased in cows fed the liquid molasses-based diets (Table 6). Similarly, replacing ground corn with increasing dietary levels of molasses or molasses-based products tend to decrease milk proportions of trans-10 C18:1 (Martel et al., 2011; Siverson et al., 2014) and total trans-C18:1 (Martel et al., 2011) and significantly decreased trans-10 C18:1 and total trans-C18:1 yields (Martel et al., 2011). Thus, previous studies (Martel et al., 2011; Siverson et al., 2014) and the current study appear to indicate that molasses increases biohydrogenation of cis-9, cis12,cis-15 C18:3, resulting in higher concentration of trans-C18:1 intermediates in the rumen. Milk proportions of cis-9,trans-11 CLA was not affected $(P=0.38)$ by the NSC supplements, which agrees with the lack of NSC effect on both milk trans-11 C18:1 $(P=0.63)$ and $\Delta^{9}$-desaturase index $(P=0.18)$ for the trans-11 C18:1/ cis-9,trans-11 CLA pair (Table 6).

\section{RDP Supplement Effects}

Although DMI was not affected $(P=0.34)$ by the RDP supplements, milk yield (-9\%), $4 \%$ FCM $(-12 \%)$, and ECM $(-10 \%)$ were all decreased $(P<0.001)$ in cows fed the flaxseed meal-based diets (Table 4). Intake of FA decreased $(P<0.001)$ by $34 \%$ (data not shown) in cows fed $\mathrm{CM}+\mathrm{FX}$ and $\mathrm{MOL}+\mathrm{FX}$, explaining, at least partly, the reduction in milk production. Moreover, RDP balance, estimated with the NRC (2001) model, ranged from negative to slightly positive (i.e., -3.3 to $8.5 \mathrm{~g} / \mathrm{d}$; data not shown) in cows fed flaxseed meal, suggesting that RDP supply may have limited milk production. Although the concentration of milk protein increased $(P<0.001)$, concentrations of milk fat $(P=0.03)$ and milk lactose $(P=0.01)$ decreased in cows fed the flaxseed meal-based diets (Table 4). Increased concentration of milk protein when feeding flaxseed meal is explained by reduced milk volume $(-1.2 \mathrm{~kg} / \mathrm{d}$; Table 4$)$. Milk proportion of trans-10, cis-12 CLA was not affected $(P=0.16)$ by the RDP supplements, but that of trans-10 C18:1 was decreased $(P<$ 0.001) as well as the trans-11 C18:1 to trans-10 C18:1 ratio, which collectively do not explain the reduction in milk fat synthesis. As suggested by Shingfield et al. (2009), other FA known to have antilipogenic activity such as cis-10,trans-12 CLA and trans-9,cis-11 CLA may have been involved.

As expected, concentration $(+74 \%)$ and yield $(+73 \%)$ of milk enterolactone were increased $(P<0.001$; Table 4 ) in cows fed the flaxseed meal diets due to the high concentration of SDG in flaxseed meal (Table 1). These results agree with previous research, which showed a positive linear response in milk enterolactone as a result of incremental dietary levels of flaxseed meal (Petit and Gagnon, 2009).

Higher versus lower blood concentrations of enterolactone and enterodiol have been associated with reduced risk of coronary diseases and colorectal adenoma in humans (Vanharanta et al., 1999, 2003; Kuijsten et 
al., 2006). A dose-response relationship was observed between flaxseed intake and serum concentration of enterolactone and enterodiol in a study conducted in healthy young women (Nesbitt et al., 1999). Moreover, a 5-fold increase in the urinary excretion of enterolactone was observed in rats fed pure enterolactone compared with those fed plant lignans (Saarinen et al., 2002). Those authors hypothesized that enterolactone may be passively absorbed along the intestinal tract, whereas plant lignans must be first converted to enterolactone by colonic microorganisms and then absorbed in a limited segment of the gut (Saarinen et al., 2002). It is important to note, however, that a large interindividual variation in the blood concentration of enterolignans has been observed in humans, thus reflecting differences in the capacity of the colonic microbiome in converting plant lignans to mammalian lignans (Nesbitt et al., 1999; Raffaelli et al., 2002). Therefore, enterolactone-enriched milk or dairy products could be used as sources of enterolactone for humans, not only because dairy foods are consumed by a large part of the US population but also due to low intake of lignans in this country (e.g., postmenopausal Caucasian women; de Kleijn et al., 2001). On the other hand, we are not aware of studies that directly link milk enterolactone with improved human health or whether the concentration of enterolactone present in milk as a result of flaxseed meal supplementation to dairy cows would be sufficient to positively affect human health. Despite potential benefits for human health (Murkies et al., 1998; Adlercreutz, 2002), high intake of phytoestrogens may also have adverse health effects, particularly in critical stages of infant development (Mendez et al., 2002; Tuohy, 2003), indicating that timing of exposure is crucial to maximize potential health benefits while minimizing adverse health effects (Steinshamn et al., 2008).

Previous research using weanling albino rats demonstrated that flaxseed upregulates the expression of hepatic genes encoding for enzymes involved in defense mechanisms against oxidative stress such as SOD, GPx, and catalase (Rajesha et al., 2006). However, neither the RDP nor the NSC supplements significantly affected the plasma concentrations of SOD or GPx in blood samples collected approximately $4.5 \mathrm{~h}$ after the morning feeding (Table 4). Recently, when feeding incremental levels of flaxseed meal $(0,5,10$, or $15 \%$ of diet DM) to lactating dairy cows, Schogor et al. (2013) reported no treatment effect for plasma concentration of SOD but did observe significant treatment $\times$ sampling time interactions for plasma GPx and catalase. These 2 antioxidant enzymes showed quadratic and cubic responses to flaxseed meal supplementation when blood samples were collected before feeding, but no responses to treatments were observed when blood samples were collected $3 \mathrm{~h}$ after feeding (Schogor et al., 2013). The lack of response of SOD and GPx (current study) and the inconsistent responses of GPx and catalase (Schogor et al., 2013) in cows fed flaxseed meal may be explained by stage of lactation (ranged from $112 \pm 21$ to $135 \pm 49$ DIM), resulting in animals less susceptible to oxidative stress.

With the exception of milk C8:0, whose proportion was not affected by the RDP supplements $(P=0.41)$, milk proportions of $\mathrm{C} 4: 0(P<0.001)$ and $\mathrm{C} 6: 0(P=$ 0.02 ) were decreased, whereas all remaining individual SFA with up to 17-carbon chain lengths were increased $(P<0.001)$ in cows fed flaxseed meal (Table 5). When dairy cows were fed incremental levels of oleamide, a fat supplement rich in cis-9 C18:1 FA, milk concentrations of all SFA with chain length $\leq 16 \mathrm{C}$, except C4:0, were linearly reduced (Jenkins, 1999). In the present study, intake of cis-9 C18:1 FA was decreased by $65 \%$ (data not shown) when feeding the flaxseed meal-based diets, which coincided with enhanced milk proportions of most short- and medium-chain SFA. Thus, it appears that de novo synthesis of short- and medium-chain SFA in the mammary gland was promoted in cows fed $\mathrm{CM}+\mathrm{FX}$ and $\mathrm{MOL}+\mathrm{FX}$. Decreased intakes (data not shown) of $\mathrm{C} 18: 0(-54 \% ; P<0.001), \mathrm{C} 20: 0(-21 \%$; $P$ $<0.001)$, and $\mathrm{C} 22: 0(-29 \% ; P<0.001)$ explain part of the effect of flaxseed meal on reduced proportions of these 3 SFA in milk fat. In fact, more than $95 \%$ of C18 and longer-chain FA present in milk fat are derived from the blood triacylglycerol-rich lipoproteins, with lipids coming from dietary sources and mobilization from body adipose tissues (Palmquist, 2006).

Out of the 50 individual unsaturated FA analyzed in milk, only 9 were not significantly affected by the RDP supplements, whereas cis-8,cis-11,cis-14,cis-17 C20:4 tended $(P=0.09)$ to increase with feeding flaxseed meal diets (Table 6). Milk proportions of individual unsaturated FA with chain length $\leq 17 \mathrm{C}$ (i.e., from C10:1 to cis-9 $\mathrm{C} 17: 1 ; \mathrm{n}=8 \mathrm{FA})$ were all increased $(P<$ $0.001)$ in cows fed flaxseed meal. With the exception of cis-6,cis-9,cis-12,cis-15 C18:4 $(P=0.03)$ and cis-11,cis14, cis-17 C20:3 $(P<0.01)$, whose milk proportions increased, the proportions of the remaining cis configuration $18 \mathrm{C}$ FA and those of $20 \mathrm{C} \mathrm{FA}$ with up to 3 double bonds were decreased $(P \leq 0.03)$ in cows fed $\mathrm{CM}+\mathrm{FX}$ and MOL+FX (Table 6 ). Although milk proportions of unsaturated FA with $\geq 20 \mathrm{C}$ were increased $(P \leq 0.02)$, milk proportion of trans-9 C16:1 $(P=0.05)$ as well as milk proportions of individual trans configuration C18:1 FA $(P<0.001)$ and the sum of trans C18:1 $(P$ $<0.001)$ were decreased in cows fed the flaxseed mealbased diets (Table 6). Collectively, differences in FA intake (data not shown), $\Delta^{9}$-desaturase indices (Table $6)$, chain elongation and desaturation of cis-9,cis- 
12,cis-15 C18:3 (Bernal-Santos et al., 2010), and rate of ruminal lipolysis and biohydrogenation (Jouany et al., 2007; Jenkins et al., 2008) may explain the changes in the milk profile of unsaturated FA when comparing the flaxseed meal-based with the protein mix-based diets.

Milk proportion of cis-9,trans-11 CLA and that of trans-11 C18:1 were both lowest $(P<0.001)$ in cows fed the flaxseed meal-based diets (Table 6). Interestingly, the $\Delta^{9}$-desaturase index for the cis-9,trans-11 CLA/ trans-11 C18:1 pair was highest with feeding $\mathrm{CM}+\mathrm{FX}$ and MOL+FX, suggesting more endogenous synthesis of cis-9,trans-11 CLA from trans-11 C18:1 in the mammary gland. Conversely, milk proportions of the $\mathrm{n}-3$ FA cis-5,cis-8,cis-11,cis-14,cis-17 C20:5 (i.e., eicosapentaenoic acid) and cis-4,cis-7,cis-10,cis-13,cis-16,cis-19 C22:6 (i.e., docosahexaenoic acid) were increased when feeding diets containing flaxseed meal. It is noteworthy, however, that the milk concentrations of these 2 n-3 PUFA were extremely low in the present study, likely as a result of extensive ruminal biohydrogenation.

\section{CONCLUSIONS}

Feeding liquid molasses-based diets (MOL and MOL+FX) significantly reduced yields of $4 \%$ FCM, ECM, and milk fat, likely due to a dilution in dietary energy compared with the corn meal-based diets (CM and $\mathrm{CM}+\mathrm{FX}$ ). Urinary $\mathrm{N}$ excretion was significantly reduced and fecal $\mathrm{N}$ excretion was significantly increased in cows fed liquid molasses, resulting in a shift in $\mathrm{N}$ excretion from urine to feces, which may have positive environmental implications. Plasma urea $\mathrm{N}$ was also reduced significantly in cows fed liquid molasses, and a significant NSC $\times$ RDP supplement interaction was observed for MUN with cows fed flaxseed meal with the lowest and highest concentrations of MUN. Concentration and yield of milk enterolactone were significantly lower in cows fed corn meal compared with those fed liquid molasses, indicating that this mammalian lignan, a bioactive compound with potential human-health benefits, can be modulated by energy supplements with different NSC profiles (i.e., starch vs. sucrose). Milk FA profile was dramatically changed by NSC and RDP supplements, likely as a result of differences in FA intake, $\Delta^{9}$-desaturase indices, and ruminal biohydrogenation pathways. Cows fed flaxseed meal-based diets (MOL+FX and $\mathrm{CM}+\mathrm{FX})$ showed depressed yields of milk and milk components as well as 4\% FCM and ECM. Based on FA composition, the flaxseed meal diets were less energy dense than their soybean-sunflower meal mix counterparts, which may partly explain these results. On the other hand, milk concentration and yield of enterolactone were significantly increased with feeding the flaxseed meal-based diets. Further research is needed to better understand the detrimental effects of flaxseed meal on milk yield when fed as the major RDP supplement in grass hay-based diets. The amount of added sugars (i.e., 7.5\% DM basis) fed with the liquid molasses-based diets was higher than the recommended level (i.e., 2.5 to 5.0\% DM basis) and may further explain the reduced animal production in cows fed MOL and MOL+FX.

\section{ACKNOWLEDGMENTS}

The authors thank the New Hampshire Agricultural Experiment Station for financial support. Gratitude is extended to Nancy Whitehouse (University of New Hampshire) and Liette Veilleux (Agriculture and AgriFood Canada/Dairy and Swine Research and Development Centre) for sample collection and technical assistance. We also thank the University of New Hampshire Burley-Demeritt Organic Dairy Research Farm former manager Trent Schrieffer and his staff for animal care and overall research support. The present research was a component of the USDA Multistate Project NC-1042.

\section{REFERENCES}

Adlercreutz, H. 2002. Phyto-oestrogens and cancer. Lancet Oncol. $3: 364-373$.

Adlercreutz, H., and W. Mazur. 1997. Phyto-oestrogens and western diseases. Ann. Med. 29:95-120.

Association of Official Analytical Chemists (AOAC). 1990. Official Methods of Analysis. 15th ed. AOAC, Arlington, VA.

AOAC International. 1998. Official Methods of Analysis. 16th ed. AOAC International, Arlington, VA.

AOAC International. 2006. Official Methods of Analyses. 18th ed. AOAC International, Gaithersburg, MD.

Baumgard, L. H., B. A. Corl, D. A. Dwyer, A. Sæbø, and D. E. Bauman. 2000. Identification of the conjugated linoleic acid isomer that inhibits milk fat synthesis. Am. J. Physiol. Regul. Integr. Comp. Physiol. 278:R179-R184.

Baumgard, L. H., J. K. Sangster, and D. E. Bauman. 2001. Milk fat synthesis in dairy cows is progressively reduced by increasing supplemental amounts of trans-10, cis-12 conjugated linoleic acid (CLA). J. Nutr. 131:1764-1769.

Bernal-Santos, G., A. M. O'Donnell, J. L. Vicini, G. F. Hartnell, and D. E. Bauman. 2010. Hot topic: Enhancing omega-3 fatty acids in milk fat of dairy cows by using stearidonic acid-enriched soybean oil from genetically modified soybeans. J. Dairy Sci. 93:32-37.

Borriello, S. P., K. D. R. Setchell, M. Axelson, and A. M. Lawson. 1985. Production and metabolism of lignans by the human fecal flora. J. Appl. Bacteriol. 58:37-43.

Broderick, G. A., N. D. Luchini, S. M. Reynal, G. A. Varga, and V. A. Ishler. 2008. Effect on production of replacing dietary starch with sucrose in lactating dairy cows. J. Dairy Sci. 91:4801-4810.

Broderick, G. A., and W. J. Radloff. 2004. Effect of molasses supplementation on the production of lactating dairy cows fed diets based on alfalfa and corn silage. J. Dairy Sci. 87:2997-3009.

Chamberlain, D. G., S. Robertson, and J. J. Choung. 1993. Sugars versus starch as supplements to grass silage: Effects of ruminal fermentation and the supply of microbial protein to the small intestine, estimated from the urinary excretion of purine derivatives in sheep. J. Sci. Food Agric. 63:189-194.

Chen, X. B., Y. K. Chen, M. F. Franklin, E. R. Ørskov, and W. J. Shand. 1992. The effect of feed intake and body weight on purine 
derivative excretion and microbial protein supply in sheep. J. Anim. Sci. 70:1534-1542.

Chizzotti, M. L., S. C. Valadares Filho, R. F. D. Valadares, F. H. M. Chizzotti, and L. O. Tedeschi. 2008. Determination of creatinine excretion and evaluation of spot urine sampling in Holstein cattle. Livest. Sci. 113:218-225.

Cochran, R. C., D. C. Adams, J. D. Wallace, and M. L. Galyean. 1986. Predicting digestibility of different diets with internal markers: Evaluation of four potential markers. J. Anim. Sci. 63:1476-1487.

Côrtes, C., N. Gagnon, C. Benchaar, D. da Silva, G. T. D. Santos, and H. V. Petit. 2008. In vitro metabolism of flax lignans by ruminal and fecal microbiota of dairy cows. J. Appl. Microbiol. 105:1585-1594.

de Kleijn, M. J., Y. T. van der Schouw, P. W. F. Wilson, H. Adlercreutz, W. Mazur, D. E. Grobbee, and P. F. Jacques. 2001. Intake of dietary phytoestrogens is low in postmenopausal women in the United States: The Framingham study. J. Nutr. 131:1826-1832.

Firkins, J. L. 2010. Addition of sugars to dairy rations. Page 91-105 in Proc. Tri-State Dairy Nutr. Conf., Ft. Wayne, IN. Pressworks Inc., Plain City, OH.

Gagnon, N., C. Côrtes, D. da Silva, R. Kazama, C. Benchaar, G. dos Santos, L. Zeoula, and H. V. Petit. 2009. Ruminal metabolism of flaxseed (Linum usitatissimum) lignans to the mammalian lignan enterolactone and its concentration in ruminal fluid, plasma, urine and milk of dairy cows. Br. J. Nutr. 102:1015-1023.

Gaines, W. L., and F. A. Davidson. 1923. Relation between percentage fat content and yield of milk. Ill. Agric. Expt. Sta. Bull. 245. University of Illinois, Urbana.

Hardie, C. A., M. Wattiaux, M. Dutreuil, R. Gildersleeve, N. S. Keuler, and V. E. Cabrera. 2014. Feeding strategies on certified organic dairy farms in Wisconsin and their effect on milk production and income over feed costs. J. Dairy Sci. 97:4612-4623.

Harfoot, C. G. 1981. Lipid metabolism in the rumen. Page 21 in Lipid Metabolism in Ruminant Animals. W. W. Christie, ed. Pergamon Press, New York, NY.

Heinonen, S., T. Nurmi, K. Kiukkonen, K. Poutanen, K. Wähälä, T. Deyama, S. Nishibe, and H. Adlercreutz. 2001. In vitro metabolism of plant lignans: New precursors of mammalian lignans enterolactone and enterediol. J. Agric. Food Chem. 49:3178-3186.

Höjer, A., S. Adler, S. Purup, J. Hansen-Møller, K. Martinsson, H. Steinshamn, and A.-M. Gustavsson. 2012. Effects of feeding dairy cows different legume-grass silages on milk phytoestrogen concentration. J. Dairy Sci. 95:4526-4540.

Hristov, A. N., J. K. Ropp, K. L. Grandeen, S. Abedi, R. P. Etter, A. Melgar, and A. E. Foley. 2005. Effect of carbohydrate source on ammonia utilization in lactating dairy cows. J. Anim. Sci. $83: 408-421$.

Jenkins, T. C. 1999. Lactation performance and fatty acid composition of milk from Holstein cows fed 0 to $5 \%$ oleamide. J. Dairy Sci. 82:1525-1531.

Jenkins, T. C., R. J. Wallace, P. J. Moate, and E. E. Mosley. 2008. Recent advances in biohydrogenation of unsaturated fatty acids within the rumen microbial ecosystem. J. Anim. Sci. 86:397-412.

Jouany, J. P., B. Lassalas, M. Doreau, and F. Glasser. 2007. Dynamic features of the rumen metabolism of linoleic acid, linolenic acid and linseed oil measured in vitro. Lipids 42:351-360.

Kuijsten, A., I. C. W. Arts, P. C. H. Hollman, P. van't Veer, and E. Kampman. 2006. Plasma enterolignans are associated with lower colorectal adenoma risk. Cancer Epidemiol. Biomarkers Prev. 15:1132-1136.

Lock, A. L., C. Tyburczy, D. A. Dwyer, K. J. Harvatine, F. Destaillats, Z. Mouloungui, L. Candy, and D. E. Bauman. 2007. Trans-10 octadecenoic acid does not reduce milk fat synthesis in dairy cows. J. Nutr. 137:71-76.

Martel, C. A., E. C. Titgemeyer, L. K. Mamedova, and B. J. Bradford. 2011. Dietary molasses increases ruminal $\mathrm{pH}$ and enhances ruminal biohydrogenation during milk fat depression. J. Dairy Sci. 94:3995-4004.

Mendez, M. A., M. S. Anthony, and L. Arab. 2002. Soy-based formulae and infant growth and development: A review. J. Nutr. $132: 2127-2130$.
Milder, I. E. J., I. C. W. Arts, B. van de Putte, D. P. Venema, and P. C. H. Hollman. 2005. Lignan contents of Dutch plant foods: A database including lariciresinol, pinoresinol, secoisolariciresinol and matairesinol. Br. J. Nutr. 93:393-402.

Muir, A. D., and N. D. Westcott. 2000. Quantification of the lignan secoisolariciresinol diglucoside in baked goods containing flax seed or flax meal. J. Agric. Food Chem. 48:4048-4052.

Murkies, A. L., G. Wilcox, and S. R. Davis. 1998. Phytoestrogens. J. Clin. Endocrinol. Metab. 83:297-303.

NRC. 2001. Nutrient Requirements of Dairy Cattle. 7th rev. ed. Natl. Acad. Sci., Washington, DC.

Nesbitt, P. D., Y. Lam, and L. U. Thompson. 1999. Human metabolism of mammalian lignan precursors in raw and processed flaxseed. Am. J. Clin. Nutr. 69:549-555.

Oelker, E. R., C. Reveneau, and J. L. Firkins. 2009. Interaction of molasses and monensin in alfalfa hay- or corn silage-based diets on rumen fermentation, total tract digestibility, and milk production by Holstein cows. J. Dairy Sci. 92:270-285.

Orth, R. 1992. Sample Day and Lactation Report. DHIA 200 FactSheet A-2. Mid-States Dairy Records Processing Center (DRPC), Ames, IA.

Palmquist, D. L. 2006. Milk fat: Origin of fatty acids and influence of nutritional factors thereon. Pages 43-92 in Advanced Dairy Chemistry. Vol. 2: Lipids, 3rd edition. P. F. Fox and P. L. H. McSweeney, ed. Springer, NY.

Petit, H. V., and C. Côrtes. 2010. Milk production and composition, milk fatty acid profile, and blood composition of dairy cows fed whole or ground flaxseed in the first half of lactation. Anim. Feed Sci. Technol. 158:36-43.

Petit, H. V., and N. Gagnon. 2009. Milk concentrations of the mammalian lignans enterolactone and enterodiol, milk production, and whole tract digestibility of dairy cows fed diets containing different concentrations of flaxseed meal. Anim. Feed Sci. Technol 152:103-111.

Raffaelli, B., A. Hoikkala, E. Leppälä, and K. Wähälä. 2002. Enterolignans. J. Chromatogr. B Analyt. Technol. Biomed. Life Sci. $777: 29-43$

Rajesha, J., K. N. C. Murthy, M. K. Kumar, B. Madhusudhan, and G. A. Ravishankar. 2006. Antioxidant potentials of flaxseed by in vivo model. J. Agric. Food Chem. 54:3794-3799.

Rotta, P. P., S. C. Valadares Filho, T. E. Engle, L. F. Costa e Silva, D. F. T. Sathler, I. N. Prado, E. G. Bonafé, F. Zawadzki, and J. V. Visentainer. 2014. The impact of dietary sugar cane addition to finishing diets on performance, apparent digestibility, and fatty acid composition of Holstein $\times$ Zebu bulls. J. Anim. Sci. 92:2641-2653

Sannes, R. A., M. A. Messman, and D. B. Vagnoni. 2002. Form of rumen-degradable carbohydrate and nitrogen on microbial protein synthesis and protein efficiency of dairy cows. J. Dairy Sci. 85:900-908

Saarinen, N. M., A. Smeds, S. I. Mäkelä, J. Ammälä, K. Hakala, J.-M. Pihlava, E.-L. Ryhänen, R. Sjöholm, and R. Santti. 2002. Structural determinants of plant lignans for the formation of enterolactone in vivo. J. Chrom. B 777:311-319.

Schogor, A. L. B., M. F. Palin, G. T. Santos, C. Benchaar, P. Lacasse, and H. V. Petit. 2013. Mammary gene expression and activity of antioxidant enzymes and oxidative indicators in the blood, milk, mammary tissue and ruminal fluid of dairy cows fed flax meal. Br. J. Nutr. 110:1743-1750.

Shingfield, K. J., A. Sæbø, P.-C. Sæbø, V. Toivonen, and J. M. Griinari. 2009. Effect of abomasal infusions of a mixture of octadecenoic acids on milk fat synthesis in lactating cows. J. Dairy Sci. 92:4317-4329.

Siverson, A., C. F. Vargas-Rodriguez, and B. J. Bradford. 2014. Short communication: Effects of molasses products on productivity and milk fatty acid profile of cows fed diets high in dried distillers grains with solubles. J. Dairy Sci. 97:3860-3865.

Soder, K. J., K. Hoffman, L. E. Chase, and M. D. Rubano. 2012. Case Study: Molasses as the primary energy supplement on an organic grazing dairy farm. Prof. Anim. Sci. 28:234-243. 
Steinshamn, H., S. Purup, E. Thuen, and J. Hansen-Møller. 2008. Effects of clover-grass silages and concentrate supplementation on the content of phytoestrogens in dairy cow milk. J. Dairy Sci. 91:2715-2725.

Stopper, H., E. Schmitt, and K. Kobras. 2005. Genotoxicity of phytoestrogens. Mutat. Res. 574:139-155.

Sukhija, P. S., and D. L. Palmquist. 1988. Rapid method for determination of total fatty acid content and composition of feedstuffs and feces. J. Agric. Food Chem. 36:1202-1206.

Thompson, L. U., P. Robb, M. Serraino, and F. Cheung. 1991. Mammalian lignan production from various foods. Nutr. Cancer $16: 43-52$.

Tuohy, P. G. 2003. Review article: Soy infant formula and phytoestrogens. J. Paediatr. Child Health 39:401-405.

USDA-AMS (Agricultural Marketing Service). 2010. National Organic Program: Access to Pasture (Livestock). 7 CFR Part 205. Accessed Oct. 10, 2014. http://www.ams.usda.gov/AMSv1.0/getfile $? \mathrm{dDocName}=$ STELPRDC5082515.

Valadares, R. F. D., G. A. Broderick, S. C. Valadares Filho, and M. K. Clayton. 1999. Effect of replacing alfalfa silage with high moisture corn on ruminal protein synthesis estimated from excretion of total purine derivatives. J. Dairy Sci. 82:2686-2696.

Van Keulen, J., and B. A. Young. 1977. Evaluation of acid-insoluble ash as a natural marker in ruminant digestibility studies. J. Anim. Sci. 44:282-287.

Van Soest, P. J., J. B. Robertson, and B. A. Lewis. 1991. Methods for dietary fiber, neutral detergent fiber, and nonstarch polysaccharides in relation to animal nutrition. J. Dairy Sci. 74:3583-3597.

Vanharanta, M., S. Voutilainen, T. A. Lakka, M. van der Lee, H. Adlercreutz, and J. T. Salonen. 1999. Risk of acute coronary events according to serum concentrations of enterolactone: A prospective population-based case-control study. Lancet 354:2112-2115.

Vanharanta, M., S. Voutilainen, T. H. Rissanen, H. Adlercreutz, and J. T. Salonen. 2003. Risk of cardiovascular disease-related and allcause death according to serum concentrations of enterolactone. Arch. Intern. Med. 163:1099-1104.

Zhou, W., G. Wang, Z. Han, W. Yao, and W. Zhu. 2009. Metabolism of flaxseed lignans in the rumen and its impact on ruminal metabolism and flora. Anim. Feed Sci. Technol. 150:18-26. 